\title{
Lactic acidosis and small cell carcinoma of the lung
}

\author{
D.S. Sheriff
}

The Salem Institute of Experimental Biology, Salem-636 001.Tn, India

\begin{abstract}
Summary: Two patients with small cell carcinoma of the lung who presented with lactic acidosis are described. Hepatocellular failure due to extensive metastases may be the cause of acute lactic acidosis.
\end{abstract}

It has been shown that lactic acidosis may be a rare metabolic complication of cancer. The accumulation of lactic acid leading to lactic acidosis in such cancer patients has been thought to be due to the occurrence of metastatic lesions (Schulier $e t$ al., 1983). Spechler $e t$ al. (1978) showed that acidosis may be the cause of death in patients with small cell (oat cell) carcinoma of the lung. In the present paper two patients with small cell carcinoma who presented with, and died of, lactic acidosis are reported.

\section{Case reports}

\section{Case 1}

A 55 year old heavy cigarette smoker complained of lethargy; there were no physical findings and laboratory investigations showed only a slightly raised blood glucose but normal blood urea, electrolytes, and liver function tests. The blood lactate was also normal at $1.2 \mathrm{mmol} / 1$. He was found to have abnormal glucose tolerance and the hyperglycaemia was controlled by diet. Eight months later he developed sudden nausea, jaundice, vomiting and hyperventilation, and was admitted to hospital. The blood pressure was $120 /$ $80 \mathrm{~mm} \mathrm{Hg}$, the plasma bilirubin was $172 \mu \mathrm{mol} / \mathrm{l}$, and the liver enzymes were grossly elevated. Arterial blood showed $\mathrm{PO}_{2} 99 \mathrm{~mm} \mathrm{Hg}, \mathrm{PCO}_{2} 14 \mathrm{~mm} \mathrm{Hg}, \mathrm{pH} 7.17$, bicarbonate $6 \mathrm{mmol} / 1$, lactate $26 \mathrm{mmol} / 1$ and glucose $5.5 \mathrm{mmol} / \mathrm{l}$. Chest X-rays showed the presence of infiltration at the left lower lobe. Blood cultures proved sterile. In spite of radiation therapy and anticancer drugs he died 5 days after admission. Autopsy confirmed the presence of small cell carcinoma with extensive metastases in the liver.

Correspondence and present address: D.S. Sheriff, M.S., Ph.D., F.A.Z., C.Biol, M.I. Biol. (UK), Post Box 7025, Berka, Benghazi, Libya.

Accepted: 24 May 1985

\section{Case 2}

A 57 year old heavy cigarette smoker complained of tiredness and was found to have mild diabetes which was controlled by diet. Some months later he developed nausea, vomiting and jaundice following which he was admitted to hospital and noted to have acidotic breathing, BP $125 / 80 \mathrm{~mm} \mathrm{Hg}$. His plasma bilirubin was $104 \mu \mathrm{mol} / 1$ and liver enzymes were considerably elevated. Arterial blood showed $\mathrm{PO}_{2}$ $98 \mathrm{~mm} \mathrm{Hg}, \mathrm{PCO}_{2} 12 \mathrm{~mm} \mathrm{Hg}, \mathrm{pH} 7.18$, bicarbonate $5.5 \mathrm{mmol} / \mathrm{l}$, lactate $25.5 \mathrm{mmol} / 1$, glucose $5 \mathrm{mmol} / 1$. Post-mortem confirmed a small cell carcinoma of the lung with extensive liver metastases.

\section{Discussion}

The liver plays an important role in lactate homeostasis along with kidneys that utilize $30 \%$ of lactate production (Kreisberg, 1980). Skin, muscle, brain and red cells are the main sites of normal lactic acid production. Liver and kidneys extract the lactate from plasma and transform it into glucose by gluconeogenesis.

It has been reported that lactic acid accumulation occurs in different forms of cancer (Schulier et al., 1983). The sudden onset of lactic acidosis in the cases presented may be due to hepatocellular failure as a result of the extensive metastases confirmed by autopsy findings. It has been shown also that hypocapnia and metabolic alkalosis are also observed in such patients, before the onset of lactic acidosis, which are known to convert the liver into an organ of lactate output independent of changes in carbon dioxide tension (Berry \& Schern, 1967). The present two cases confirm earlier observations that lactic acidosis may be a rare complication of small cell carcinoma and may indirectly indicate hepatocellular failure due to extensive metastases. 


\section{Acknowledgements}

I thank Dr H.M. Iqbal Ahmed and Dr P. Radhamani for their help in completing the studies in the patients and the Salem Institute of Experimental Biology, Salem, India for their encouragement and facilities provided to do the work.

\section{References}

BERRY, M. \& SCHERN, J. (1967). Splanchnic lactic acid metabolism in hyperventilation, metabolic alkalosis and shock. Metabolism, 16, 537.

KREISBERG, R.A. (1981). Lactate homeostasis and lactic acidosis. Archives of Internal Medicine, 138, 1613.

SCHULIER, J.P., NICAISE, C. \& KLASTERSKY, J. (1983).
Lactic acidosis; a metabolic complication of extensive metastatic cancer. European Journal of Cancer and Clinical Oncology, 1, 597.

SPECHLER, S.J., ESPOSITE, A.L., KOFF, R.S. \& HANG, W.K. (1978). Lactic acidosis in oat cell carcinoma with extensive hepatic metastases. Archives of Internal Medicine, 13, 1663. 